\title{
Comparative analysis of indicators for assessing the state of activated sludge in the water treatment process
}

\author{
(c) Yelena S. Balymova, ${ }^{+}$Yulia M. Safiullina, \\ Farida Yu. Akhmadullina, and Rustem K. Zakirov \\ Department of Industrial Biotechnology. Faculty of food Technologies. \\ Kazan National Research Technological University. Karl Marx St., 68. Kazan, 420015. \\ Republic of Tatarstan.Russia.Phone:+7 (843)231-43-28.E-mail: ilc2013@inbox.ru
}

\begin{abstract}
*Supervising author; ${ }^{+}$Corresponding author
Keywords: activated sludge, hydrobiological analysis, the point system, the Shannon index, the Cube index.
\end{abstract}

\begin{abstract}
This article presents the results of biodiagnostics of activated sludge formed in the wastewater of organic synthesis plants. They are characterized by changes in the concentrations of control pollutants (phenol, non-ionic synthetic surfactants, glycols), as well as chemical oxygen demand in a fairly wide range, which negatively affects at the activated sludge state and does not allow to achieve the regulatory requirements for the quality of treated wastewater. In this paper, the state of active biomass in the process of biological wastewater treatment was evaluated using three quantitative assessment systems: a five-point scale, hydrobiological indices of biodiversity Shannon and Cuba. The paper presents a comparative analysis of systems for quantifying the state of activated sludge, that are recommended for use in water treatment practice, both for simple systems, in which only one control factor affects the state of activated sludge, and for complex systems, that include the impact of a large number of control ecotoxicants on the activated sludge ecosystem. It is shown that in quantitative terms, the established regularities of the influence of control pollutants on the state of activated sludge differ: the five-point evaluation system, in comparison with the Shannon index, reflects deeper changes in the state of the biocenosis, because it evaluates not only the number of hydrobionts, but also their state, as well as the state of activated sludge flakes and the liquid above it. However, the assessment of the activated sludge state by the Cube index revealed a quantitative discrepancy in the change of this index compared to the aforementioned, which suggests that it is not appropriate to use it to describe the dynamics of changes in the state of the bioagent in the process of water treatment.
\end{abstract}

\section{References}

[1] D.V. Tyupa, S.V. Kalenov, and N.A. Suyasov. Heavy metal biosorbents based on activated sludge micromycetes. Butlerov Communications. 2017. Vol.50. No.5. P.57-64. DOI: 10.37952/ROI-jbc-02/17-50$5-57$

[2] L.M. Sibieva, T.V. Vdovina, A.S. Sirotkin, I.A. Degtyareva, E.T. Vakhitova, and P.F. Khaeva. Assessment of the activated sludge toxicity in technologies of biological and physico-chemical wastewater treatment. Butlerov Communications. 2018. Vol.56. No.12. P.162-170. DOI: 10.37952/ROIjbc-02/18-56-12-162

[1] N.S. Zhmur. Technological and biochemical processes of wastewater treatment at facilities with aerotanks. AQUAROS. 2003. 512p. (russian)

[2] I.I. Rogovskaya. Recommendations for methods of production of analyses at the facilities of biochemical treatment of industrial waste water. Moscow: Publishing house of literature on construction. 1970. 99p. (russian)

[3] L.A. Kutikova. The fauna of the aeration tanks: atlas. Leningrad: Nauka. 1984. 264p. (russian)

[4] F.Y. Achmadulina, R.K. Zakirov, E.S. Balymova, V. Denisova, T. Brovdyová, J. Trögl, M. Neruda. Comparison of bioindicator eukaryotes of activated sludge biocenoses on two water-treatment plants: A case study. Nova Biotechnologica et Chimica. 2017. Vol.1, Vol.16. P.54-60.

[5] Ye.S. Balymova. Express-control method for managing the process of biological treatment of the petrochemical complex waste water (on the example of JSC «Kazanorgsintez»). PhD Thesis for technical sciences. Kazan. 2015. 151p. (russian) 
[6] C.E. Shannon. The mathematical theory of communication. Bell Syst. Techn. J. 1948. Vol.27. P.379-423, 623-656.

[7] N.S. Zhmur. Methodological guide to hydrobiological and bacteriological control of the process of biological treatment at facilities with aerotanks. ERD SB F 14.1.77-96. Moscow: IPK publishing house of standards. 1996. 37p. (russian)

[8] T.R. Cuba. Diversity: two-level appoach. Ecolody. 1981. Vol.62. P.278-279.

[9] N.S. Zhmur. Biocenotic changes of activated sludge, functioning under extreme anthropogenic impact. Thesis of the doctor of biological sciences. Moscow. 2000. 290p. (russian)

[10] Ye.S. Balymova, R.K. Zakirov, R.R. Gainetdinova, F.Yu. Akhmadullina. Biodiagnostics of activated sludge as a method of express control of biological wastewater treatment. Security in the technosphere. 2012. Vol.4. P.11-16. (russian)

[11] Patent № 2415086, IPC C02F 3/02. Kirsanov V. V., Kudryashov V. N., Gafurov R. R., Khuzayanov R. H., Smolko A. A., Gitsareva E. V. Method for increasing the efficiency of biological treatment of chemically contaminated wastewater, applicant and patent holder Kazan open joint stock company «Organic synthesis» (JSC «Kazanorgsintez»). Published: 27.03.2011. Bulletin No.9. 9p. (russian)

[12] Ye.S. Balymova, F.Yu. Akhmadullina, R.K. Zakirov. Biomonitoring of industrial sludge process extended aeration wastewater. Water: chemistry and ecology. 2010. No.9. P.29-34 (russian) 